\title{
Histopathology and prognostic factors in bronchial carcinoid tumours
}

\author{
P S Hasleton
}

Donald Heath will always be remembered for his contribution to our understanding of the pulmonary circulation, high altitude pathology, and the rediscovery of the carotid body. He was fascinated by the concept of the neuroendocrine lung, and played a part in an early study of the clinicopathological behaviour of bronchopulmonary carcinoid tumours. ${ }^{1}$ Twenty two tumours were examined and their histology was reviewed blind by Professor Heath. The surgeon writing the paper therefore had the opinion of two histopathologists and, as he stated, "this method, although unfair to the pathologist, seemed one by which an assessment of the importance of the histology might be made. Its shortcomings were apparent, one being that although the histological appearance was the criterion for admission of a patient to the series, its importance was in part denied in assessing the ultimate outcome". The histological appearances were divided into "regular" with "orderly cell arrangement", and "irregular" with "pleomorphism, unusual arrangement or occasional mitosis".

The problems encountered in histological diagnosis, which remain to some extent today, were illustrated by three cases. They were classified as "irregular", "regular", and "irregular" by one observer and "malignant but not carcinoid", oat-cell carcinoma, and "regular", respectively, by the other. This led the surgeon to question the value of the histological appearance in assessing prognosis in these tumours.

This review will focus on studies undertaken mainly after 1969 to address the clinicopathological correlation in bronchopulmonary carcinoid tumours, and methods of predicting their biological behaviour.

\section{Clinical aspects}

While carcinoid tumours comprise approximately $85 \%$ of benign lung tumours, they account for only $1-2 \%$ of all lung tumours. ${ }^{2}$ In four large series ${ }^{3-6}$ there was a female predominance $(1 \cdot 2: 1 \cdot 0)$ with an age range of $12-82$ years and a mean of 50 years. A recent study of lung tumours in paediatric patients from the Massachusetts General Hospital in Boston showed that carcinoid tumours were the most frequently encountered primary pulmonary neoplasms in this age group. ${ }^{7}$

Carcinoid tumours may be central or peripheral. If central they are more common on the right side and present with haemoptysis or recurrent bronchial obstruction. Chest pain, pleural effusion, cough, wheeze, hoarse voice, atelectasis, or dyspnoea may also be presenting features, but nearly $20 \%$ of cases are asymptomatic. ${ }^{5}$

Endocrine manifestations, including the carcinoid syndrome ${ }^{8}$ with left sided valvular lesions, are rare with an incidence of $1-7 \% .^{9-11}$ This may be because the amount of tumour tissue present is insufficient to produce the mediators responsible for the syndrome, or because the peptides, prostaglandins, kinins, and other mediators produced by these tumours are rapidly inactivated by the lung and liver. ${ }^{12}$ The syndrome occurs most commonly in pulmonary carcinoid tumours with metastases. ${ }^{413}$ These arguments do not allow for tumours draining into the left atrium via the pulmonary veins. Although immunocytochemical examination can demonstrate many peptides and other mediators in these tumours, this technique may be particularly sensitive or the total amount of mediator produced may be too small to cause valvular disease.

Acromegaly, ${ }^{14}$ Cushing's syndrome, ${ }^{15}$ and insulin production with hypoglycaemia ${ }^{16}$ are also rare. The tumour may be part of the multiple endocrine adenomatosis syndrome. Elevated levels of growth hormone releasing hormone may be detected without acromegaly. ${ }^{17}$ More recently hypercalcaemia has been described in atypical bronchial carcinoid tumours; it is not known whether this is the result of osteolytic metastases or whether there is some other tumour associated cause. ${ }^{18}$

Only $60-77 \%$ of tumours are visible through a bronchoscope. They bleed easily and this feature has been cited as a contraindication to biopsy. ${ }^{19}$ However, a study describing 33 years of surgical experience with this tumour found appreciable haemorrhage in only two cases, and both were easily controlled. ${ }^{20}$

\section{Classification}

Carcinoid tumours are thought to have an origin in either neuroendocrine cells or neuroepithelial bodies. Warren et $a l^{21}$ classified these tumours as neuroendocrine neoplasms - that is, those tumours whose predominant pattern is neuroendocrine - in contrast to those with squamous or glandular differentiation. They recognised four categories: bronchial carcinoid tumours (previously called typical carcinoid tumours), well differentiated neuroendocrine carcinomas, intermediate small cell neuroendocrine carcinomas, and small cell neuroendocrine carcinomas. Well differentiated neuroendocrine carcinoma is otherwise known as atypical carcinoid and the diagnosis is based on the microscopic features of necrosis, lymph- 


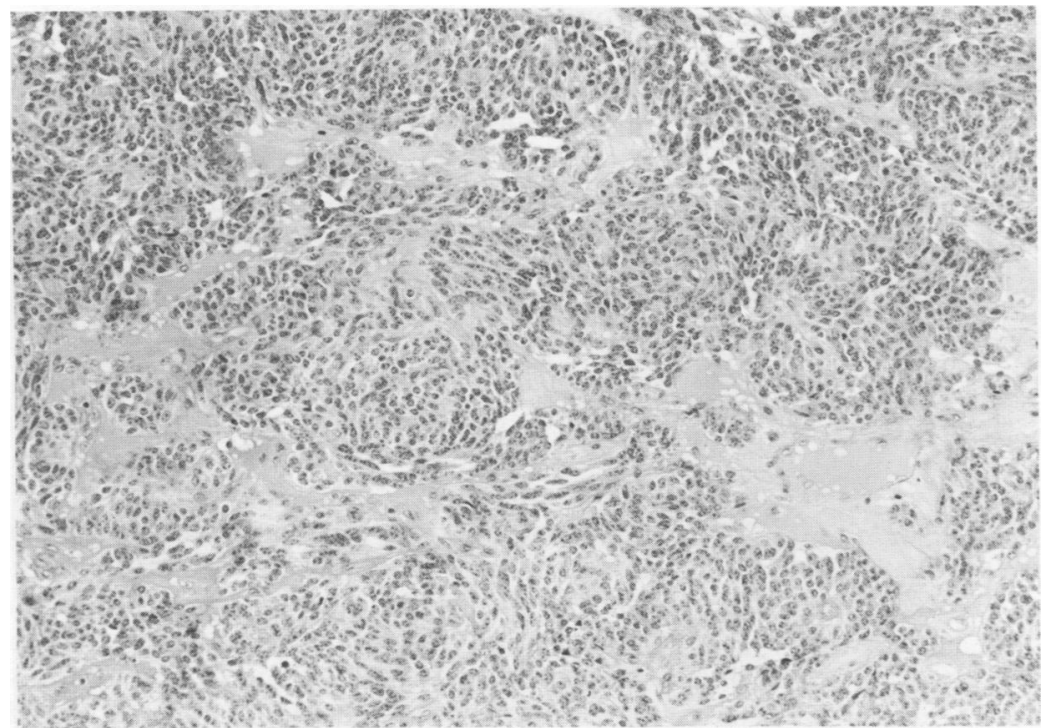

Figure 1 Typical bronchial carcinoid tumour with a predominantly insular pattern. Stain: haematoxylin and eosin, original magnification $\times 125$ reduced to $63 \%$ in origination. atic or vascular permeation, mitoses, nuclear pleomorphism, and an undifferentiated growth pattern. ${ }^{22}$ An undifferentiated growth pattern may coexist with trabecular, insular, or acinar areas and is defined as one where it is impossible to define one of the other three growth patterns as identified above. The presence of lymph node metastases, while suggesting a well differentiated neuroendocrine carcinoma, should not be taken as evidence that the tumour is behaving in a malignant fashion in all cases. We have seen occasional cases with a typical carcinoid pattern, lymph node metastases, and a long postoperative survival. When larger series are analysed the presence of lymph node metastases is an adverse prognostic factor.

Endobronchial biopsies from well differentiated neuroendocrine carcinomas may be misdiagnosed as small cell carcinoma. This is usually because of sampling error and, when the lung is removed, areas with a definite carcinoid

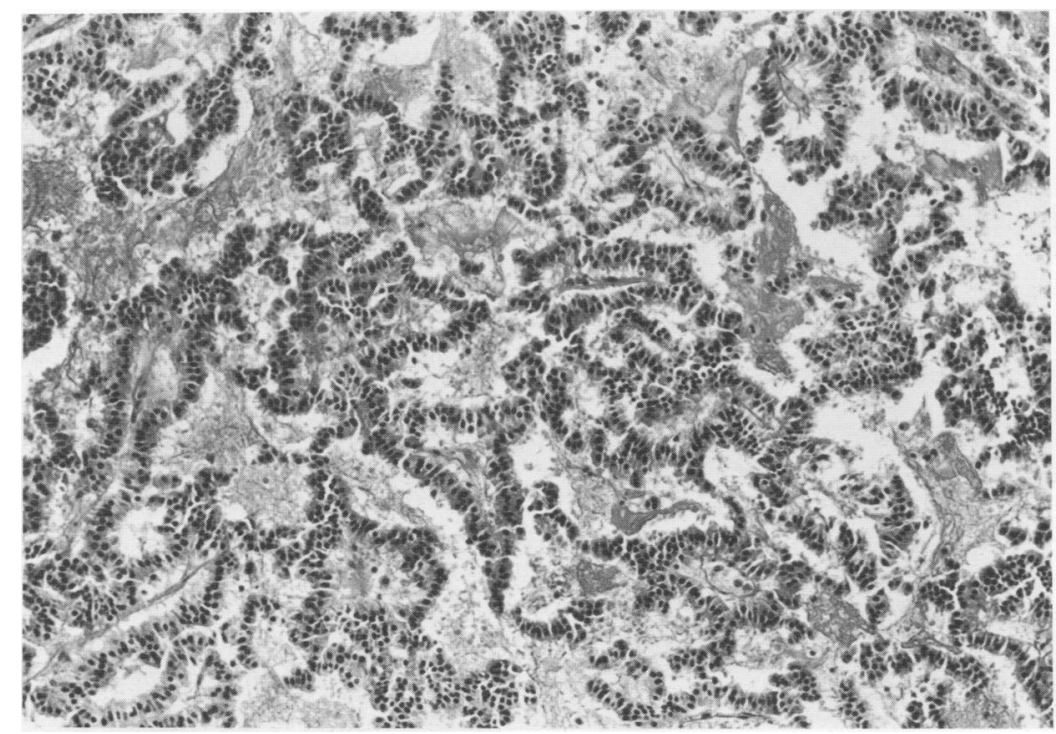

Figure 2 Typical carcinoid tumour with trabecular growth pattern. Stain: haematoxylin and eosin, original magnification $\times 125$ reduced to $63 \%$ in origination. pattern are identified. It is therefore important that as large a biopsy specimen as possible is obtained so that the correct diagnosis can be made. The prognosis for well differentiated neuroendocrine carcinoma is better than for small cell carcinoma. ${ }^{2324}$ Large cell neuroendocrine carcinoma ${ }^{25}$ should also be added to this classification.

While atypical carcinoid tumours (well differentiated neuroendocrine carcinoma) and small cell neuroendocrine carcinoma have different histological patterns and prognoses, the concept of neuroendocrine carcinoma is a useful one in identifying the cell of origin.

\section{Histology}

Typical carcinoid tumours show many patterns, some of which cause diagnostic difficulty. The commonest is mixed with insular (fig 1) and trabecular foci (fig 2). A pure acinar pattern is uncommon. Tumours without these characteristics are termed undifferentiated (fig 3) and are classed with atypical carcinoid tumours. The cells are uniform with regular central nuclei and a faintly eosinophilic cytoplasm. Oncocytic change may be focal or, rarely, diffuse (fig 4), thereby classifying the tumour as an oncocytic carcinoid. Oncocytic carcinoid tumours show neurosecretory granules as well as mitochondrial hyperplasia. Ghadially and Block $^{26}$ described filamentous mitochondrial inclusions and calcified spherules which appeared to develop in material secreted by tumour cells. Carcinoid tumours may rarely complicate cryptogenic pulmonary fibrosis or occur synchronously with an adenocarcinoma of the lung.

Papillary (fig 5), goblet cell, and melanin-containing cells or spindle cell patterns (fig 6 ) have been described in typical carcinoid tumours. ${ }^{227}$ Mark et $a l^{8}$ have described a papillary carcinoid which must be distinguished from a papillary adenoma. Pure spindle cell carcinoid tumours, usually subpleural, are uncommon. ${ }^{29}$ They have monomorphic spindle cells arranged in fascicles and loose groups. In some cases the organoid pattern of carcinoid tumours is identified. There is no significant cytological atypia or nuclear pleomorphism. Mitoses are few. Rare tumours may show signet ring cells or a bronchioloalveolar carcinoma pattern. ${ }^{30}$ Mucin may be detected in carcinoid tumours, both by light and electron microscopy.

The stroma is vascular and may undergo hyaline change, calcification and, in some cases, shows the presence of amyloid. ${ }^{31}$ The epithelium covering the luminal aspect of central carcinoid tumours frequently undergoes squamous metaplasia and, in some cases, may appear mildly dysplastic. By definition necrosis, mitoses, and nuclear pleomorphism are not seen in typical carcinoid tumours. Any of these features should make one suspect a well differentiated neuroendocrine carcinoma (figs 7 and 8).

In a study of 35 bronchial carcinoid tumours there was a tendency for invasion beyond the bronchial wall to be associated with a poorer prognosis, but this did not reach statistical significance. ${ }^{32}$ 


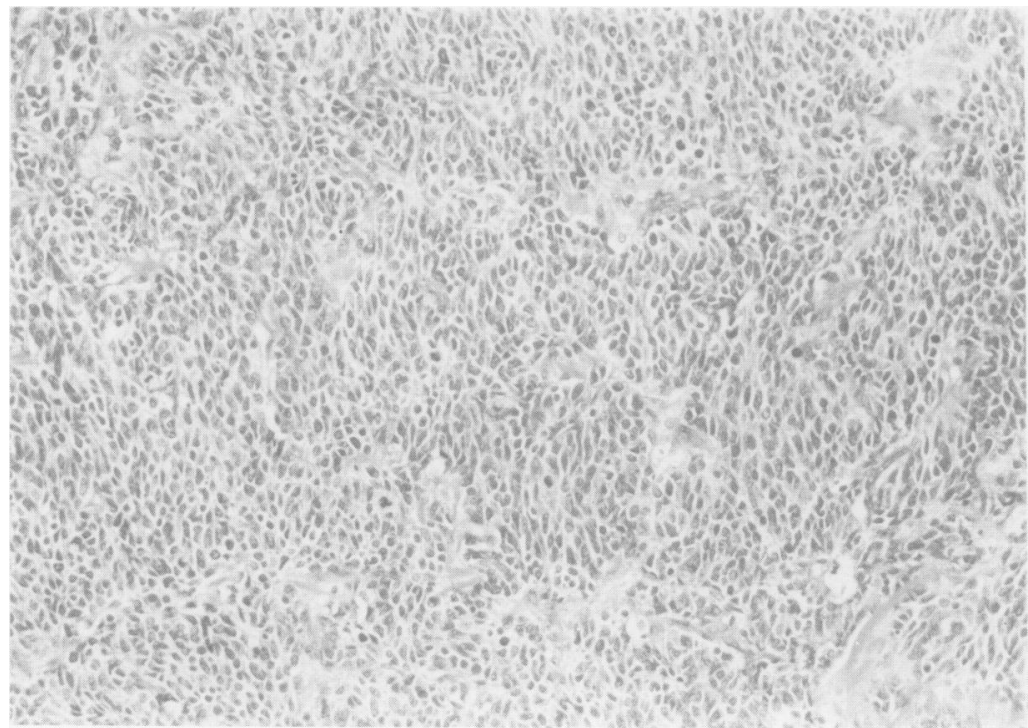

Figure 3 Atypical carcinoid (well differentiated neuroendocrine carcinoma) with a disorganised histological structure. Stain: haematoxylin and eosin, original magnification $\times 125$ reduced to $63 \%$ in origination.

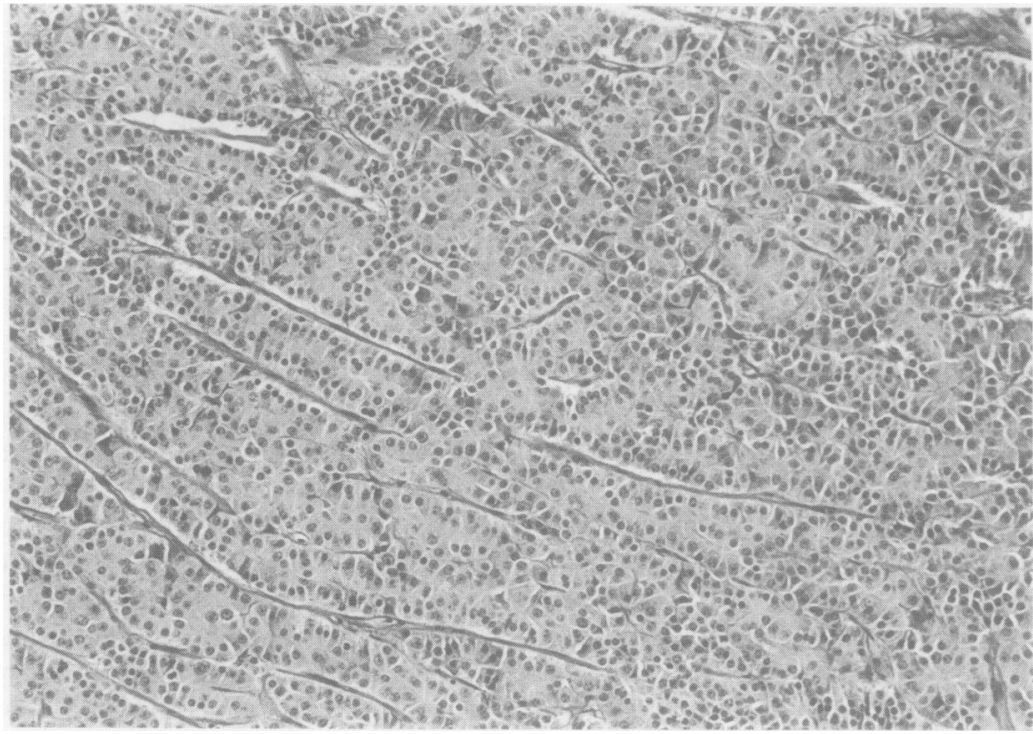

Figure 4 Oncocytic carcinoid tumour. Stain: haematoxylin and eosin, original magnification $\times 125$ reduced to $63 \%$ in origination.

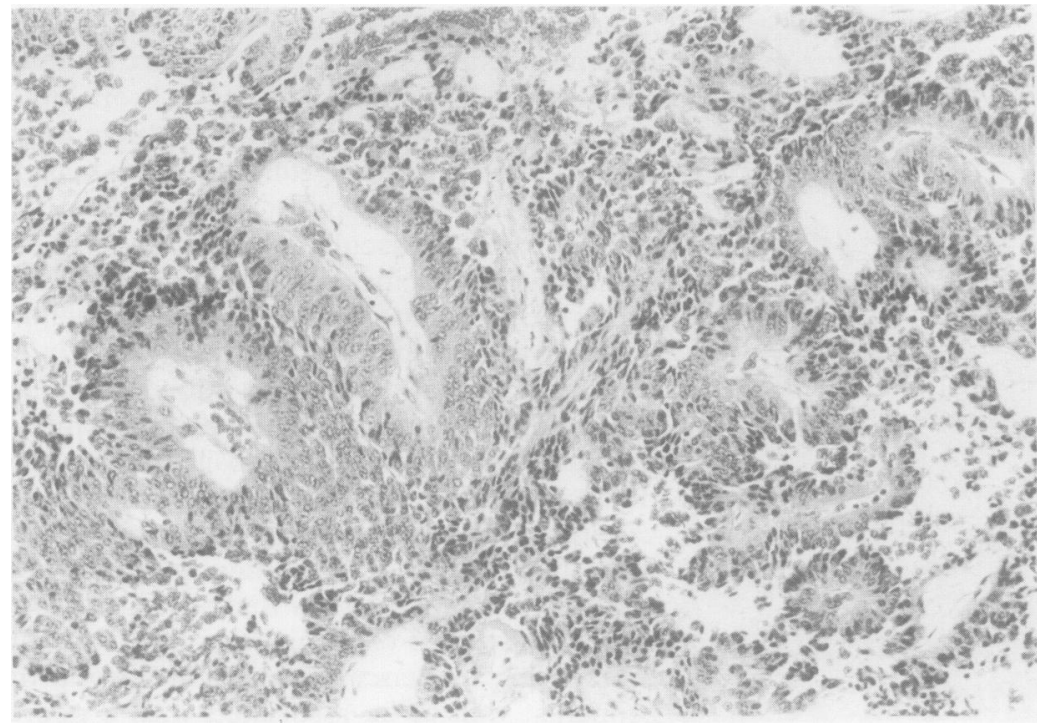

Figure 5 Papillary carcinoid tumour. Stain: haematoxylin and eosin, original magnification $\times 125$ reduced to $63 \%$ in origination.

\section{Bone formation in bronchial carcinoid}

\section{tumours}

Between $10 \%{ }^{33}$ and $25 \%$ of bronchial carcinoma tumours contain bone ${ }^{22}$ (fig 9 ). If peripheral carcinoid tumours are excluded this figure rises to $30 \%$. This ability to produce bone appears to be largely confined to bronchial tumours since it is almost never seen in ileal or appendiceal carcinoid tumours. In some cases bone is present in relation to bronchial cartilage, but in many it is seen in the middle of the tumour. Cartilage may also be found in some tumours and may play a part in bone formation.

The mechanism of bone formation is unknown. Cooney et $a l^{34}$ believed that it was the result of locally produced calcitonin and found this hormone immunocytochemically in four of seven bone-containing carcinoid tumours However, medullary carcinoma of the thyroid, a tumour rich in calcitonin, shows calcification but no bone, ${ }^{35}$ and we have found carcinoid tumours with no bone but with calcitonin immunoreactivity. ${ }^{22}$ Acid phosphatase and 5nucleotidase have also been suggested as the cause of the ectopic bone, but a recent case was negative for both these enzymes. ${ }^{36}$

We have recently demonstrated IGF-1 (insulin growth factor 1) in bronchial carcinoid tumours. This growth factor is mitogenic for various mesoderm-derived cells in vitro, ${ }^{37}$ and functions both in an endocrine manner as well as locally within tissues in a paracrine/autocrine mode associated with other growth factors. The main role of IGF-1 is in the growth of young mammals, and its production is regulated by pituitary growth hormone whose growth-promoting activity on skeletal tissues it, in its turn, mediates. ${ }^{38} 39$ Insulin growth factors are unique in that they can stimulate both growth and differentiation.

\section{Individual cell death in carcinoid tumours}

A second population of smaller cells with little cytoplasm and hyperchromatic nuclei (fig 10) is easily identified in all carcinoid tumours. These cells are randomly scattered with sparse cytoplasm and very dense basophilic nuclei. There is a spectrum of nuclear changes ranging from single, ovoid, irregular structures to multiple fragments. They have been shown ultrastructurally to be undergoing necrosis or cell death, with clumping of the nuclear chromatin, blebbing of the nuclear membrane, and markedly swollen mitochondria. ${ }^{40}$

Morphometric analysis of individual cell death in 51 bronchial carcinoid tumours showed the cell death index calculated as the number of dead cells per field/intact plus dead cells per field, was not significantly different for typical and atypical bronchial carcinoid tumours being $17 \%$ and $13 \%$, respectively. ${ }^{40}$ Care was taken not to analyse regions of tumours that did not show gross coagulative necrosis. Individual cell death did not appear to be positively associated with poor prognosis in the atypical carcinoid tumours. The proportion of cells dead or dying was higher than the ranges 


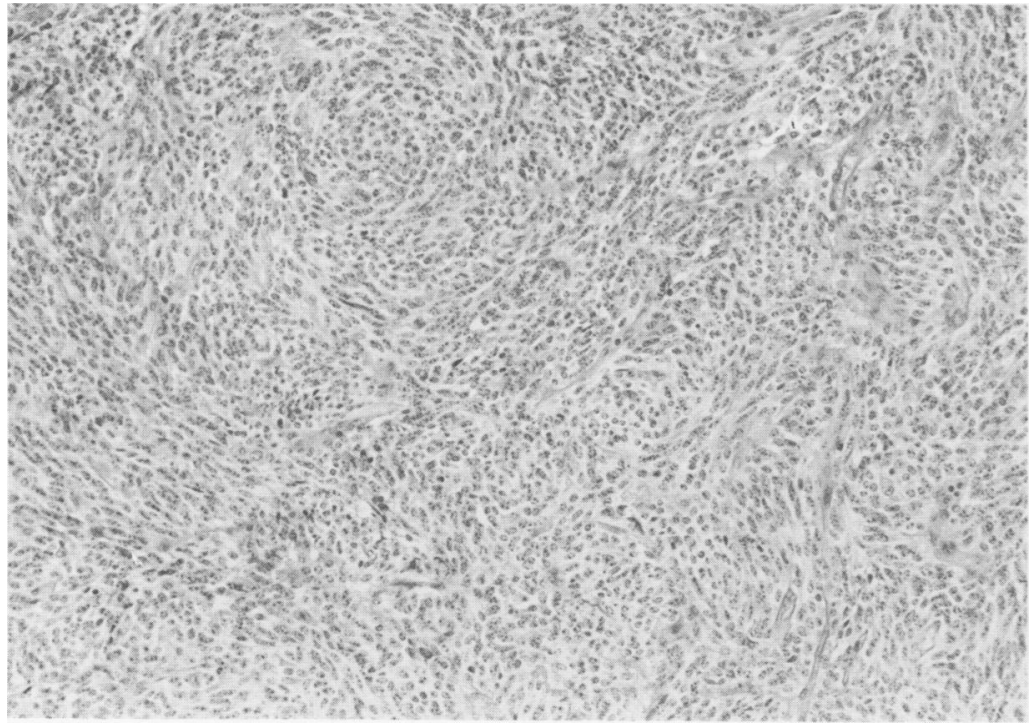

Figure 6 Carcinoid tumour with spindle cell pattern. Stain: haematoxylin and eosin, original magnification $\times 125$ reduced to $63 \%$ in origination.

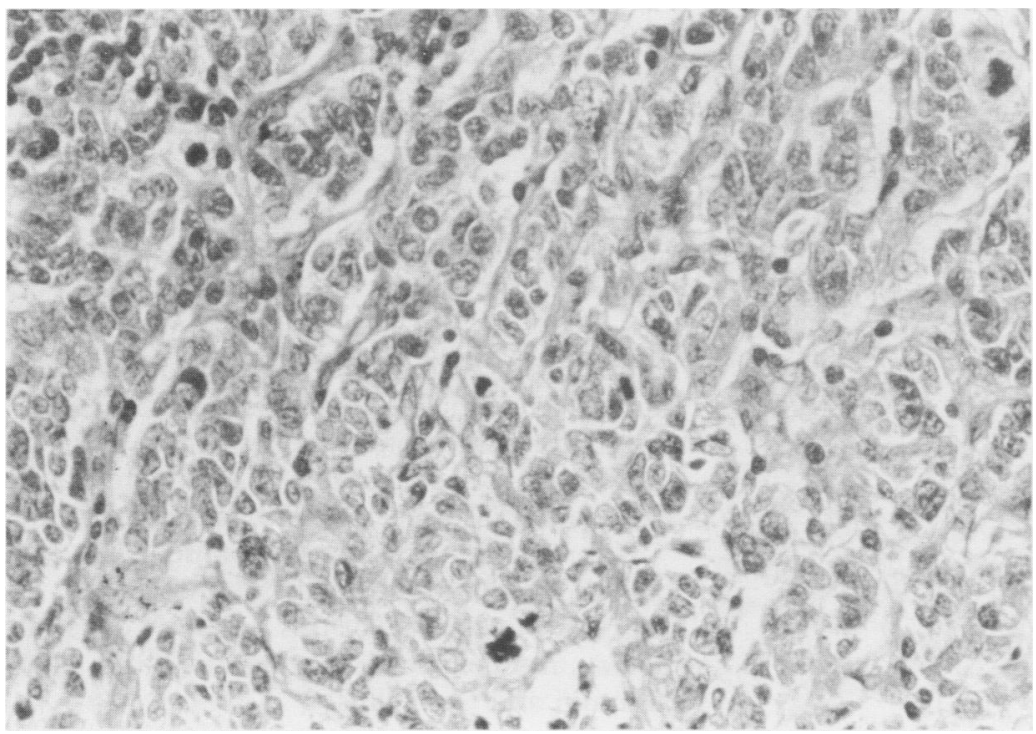

Figure 7 Well differentiated neuroendocrine carcinoma with nuclear pleomorphism and an undifferentiated growth pattern. Stain: haematoxylin and eosin, original magnification $\times 313$ reduced to $63 \%$ in origination.

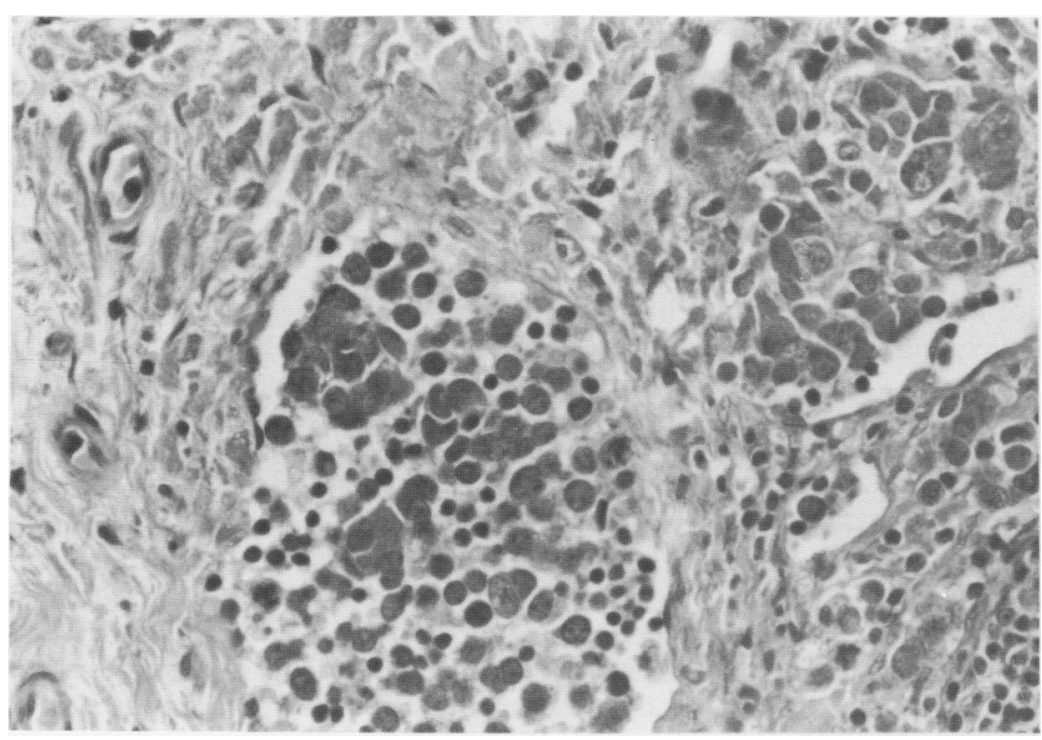

Figure 8 Lymphatic permeation in a well differentiated neuroendocrine carcinoma. Stain: haematoxylin and eosin, original magnification $\times 313$ reduced to $63 \%$ in origination. quoted for "apoptotic" indices in rodent tumours $(0 \cdot 3-7 \%)^{41}$ or in squamous carcinomas of the uterine cervix and bronchus $(1 \cdot 5-10 \%) .^{42}$ In diploid tumours the proportion of dead cells was $18 \%$ and in aneuploid $12 \%$. It would therefore appear that bronchial carcinoid tumours, even when typical, have a high cell death rate. It is interesting to speculate on whether this is due to the production of peptides or growth factors in some way driving cell growth and accelerating cell death.

\section{Ploidy in bronchopulmonary carcinoid tumours}

As cytogenetic changes are a recognised feature of many human tumours and may be related to clinical behaviour, it was thought that DNA ploidy may be of independent prognostic value. This hope was not fulfilled and DNA ploidy did not confer any independent prognostic information in bronchial carcinoid tumours. In a study of 53 patients those with DNA diploid tumours tended to survive longer than those with DNA aneuploidy, ${ }^{43}$ but the difference was of borderline statistical significance (fig 11). It is possible that statistical significance for survival between aneuploid and diploid status might be reached in a larger study. Well differentiated neuroendocrine carcinomas showed a greater tendency to be aneuploid than typical carcinoid tumours (table 1). The incidence of DNA aneuploidy in tumours with lymph node metastases $(11 / 13,85 \%)$ was significantly higher than those without $\left(12 / 36,33 \% ; \chi^{2}=8 \cdot 1, \mathrm{p}<0 \cdot 02\right)$. Two typical tumours had lymph node metastases and were DNA aneuploid. In a Cox multivariate analysis the most powerful predictor of prognosis was the histological growth pattern. The other variables of independent significance were the presence of involved lymph nodes and the presence of nuclear pleomorphism.

Another flow cytometric study of 47 bronchopulmonary carcinoid tumours confirmed the above findings and showed that aneuploidy was more common in tumours of $3 \mathrm{~cm}$ or more in diameter. ${ }^{44}$ The main difference was a high percentage of diploid tumours in our study. This may have been due to underdetection of near-diploid aneuploidy.

The presence of aneuploidy in typical carcinoid tumours limits the value of flow cytometry diagnostically, although this analysis does have some prognostic benef...

\section{Special stains in bronchial carcinoid tumours}

The most commonly used stain is Grimelius which was positive in 46 of 63 cases in one series. ${ }^{22}$ Diastase-PAS was positive in 13 cases. Carcinoembryonic antigen was detected in approximately half the cases, and there was a tendency for stronger staining in atypical carcinoid tumours. Carcinoembryonic antigen reactivity is a strongly significant factor for predicting treatment failure. ${ }^{45}$

A list of peptides present in bronchial carcinoid tumours is given in table $2 .^{46}$ There is a 


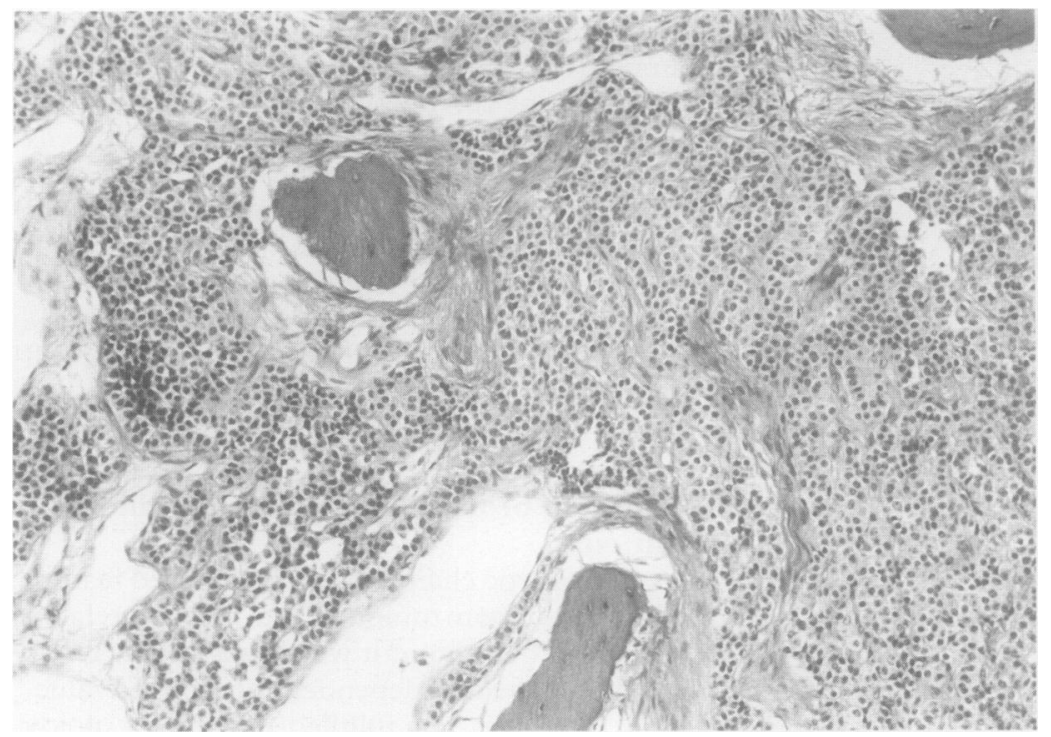

Figure 9 Typical carcinoid tumour with bone formation. Stain: haematoxylin and eosin, original magnification $\times 125$ reduced to $63 \%$ in origination.

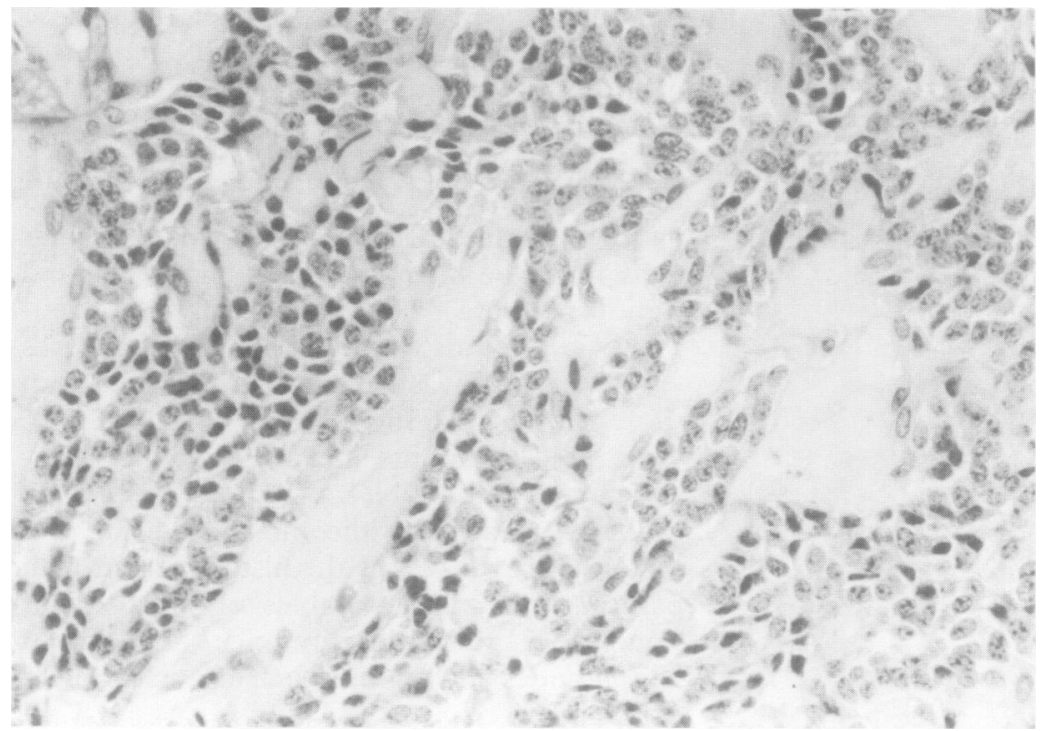

Figure 10 Small cells with hyperchromatic nuclei in a carcinoid tumour showing intervening fibrosis. Stain: haematoxylin and eosin, original magnification $\times 313$ reduced to $63 \%$ in origination.

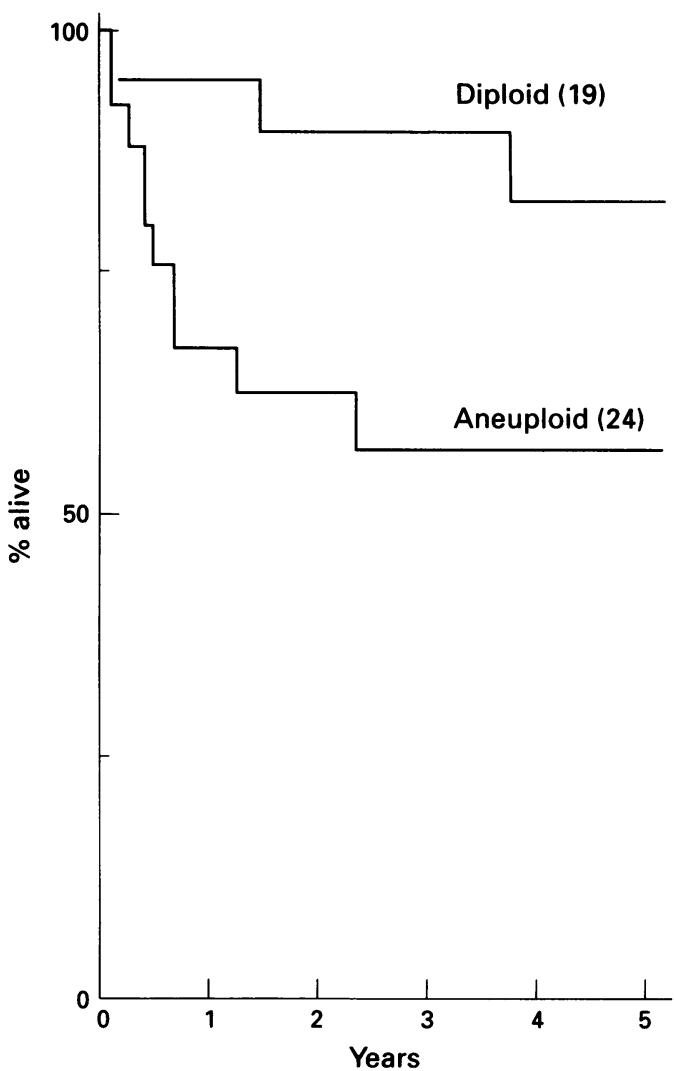

Figure 11 Ploidy status related to survival in bronchial carcinoid tumours.

to be of little help in the diagnosis of carcinoid tumours or small cell lung cancer; ${ }^{52} 70 \%$ of small cell carcinomas stained for neurone specific enolase, but 14 of 21 non-small cell carcinomas also reacted with this antiserum.

Neurofilament proteins are expressed in carcinoid tumours, especially neurofilament 70 (fig 12), but the use of this antibody does not detect more carcinoid tumours than prealbumin and Grimelius. ${ }^{53}$

\section{Prognostic indices in bronchial carcinoid tumours}

The most significant clinical features affecting prognosis are increasing age, tumour diameter above $3 \mathrm{~cm}, \mathrm{~T}$ stage, $\mathrm{N}$ stage, lymph node involvement, number of lymph nodes involved, and number of cigarettes smoked per day. The last factor should not be thought of as a causal factor but is merely an expression of the increased operative risk attendant on this habit. $^{32}$

The histological features related to survival are necrosis, increased mitotic count, nuclear pleomorphism, lymphatic and vascular invasion, and an undifferentiated growth pattern. However, even with all these variables there are still cases which behave like true endocrine tumours and follow no set pattern. One such case of a typical carcinoid tumour with regional metastases at operation was described by Bertelsen et al. ${ }^{3}$ Despite this adverse prognostic factor the patient was alive and free from tumour 12 years later.

Thus, while criteria have been refined for the assessment of malignancy in carcinoid study $^{51}$ chromogranin (type unspecified) was detected in all bronchial carcinoid tumours but not in small cell carcinomas.

Bergh et al found neurone specific enolase 


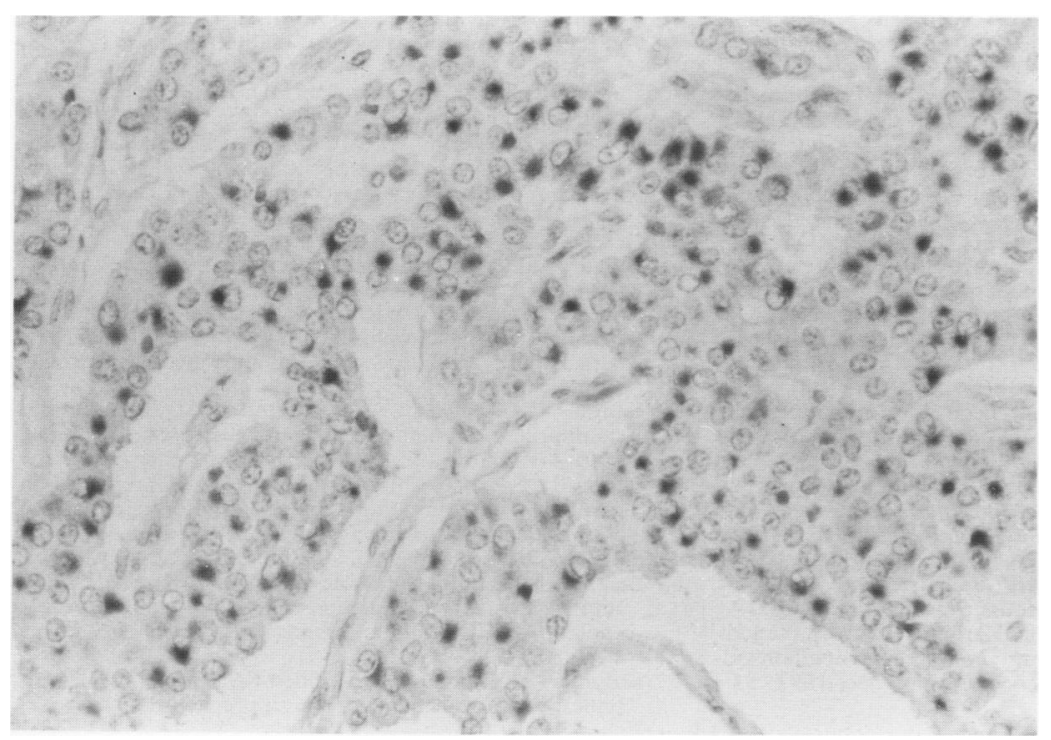

Figure 12 Neurofilament 70 with a perinuclear distribution in a typical carcinoid tumour. Stain: immunoperoxidase, original magnification $\times 313$ reduced to $63 \%$ in origination. tumours, the point made by Abbey Smith ${ }^{1}$ that the surgeon should remain cautious when giving patients a full prognosis based solely on histological criteria remains valid.

1 Abbey Smith R. Bronchial carcinoid tumours. Thorax 1969; 24:43-9.

2 Carter D, Eggleston JC. Tumors of the lower respiratory tract. In: Atlas of tumor pathology. Washington: AFIP, 1983 . 162.

3 Bertelsen S, Aasted A, Lund C, Badsberg E, Christofferson I, Jacobson $M$, et al. Bronchial carcinoid tumours: clinicopathologic study of 82 cases. Scand $\mathcal{f}$ Thorac Car diovasc Surg 1985;19:105-11.

4 McCaughan BC, Martini N, Bains MS. Bronchial carcinoids: review of 124 cases. $\mathcal{F}$ Thoracic Cardiovasc Surg 1985;89:8-17.

5 Martensson H, Bottcher G, Hambraeus G, Sundler F, Willen $\mathrm{F}$, Willen $\mathrm{H}$, et al. Bronchial carcinoids: an analysis of 9 cases. World Surg 1987;111:356-64.

6 Todd TR, Cooper JD, Weissberg D, Delarue NC, Griffith Pearson F. Bronchial carcinoid tumours: twenty years experience. $f$ Thorac Cardiovasc Surg 1980;79:532-6.

7 Wang LT, Wilkins EW, Bode HH. Bronchial carcinoid tumors in pediatric patients. Chest 1993;103:426-8.

8 Knolt-Craig CJ, Schalf HV, Mullany CJ, et al. Carcinoid disease of the heart: surgical management of ten patients. f Thorac Cardiovasc Surg 1992;104:475-81.

9 Robbins SL, Cotran RS, Kumar V. Pathological basis of disease. 3rd edn. Philadelphia: Saunders, 1984.

10 Wilkins ER Jr, Darling RC, Soutter L, Sniffen RC. A continuing survey of adenomas of the trachea and bronchus in a general hospital. $f$ Thorac Cardiovasc Surg 1963 46:279-91.

Table 1 Histological features and their relation to ploidy

\begin{tabular}{lllll}
\hline Histological features & No. & Ploidy & $\varkappa^{2}$ & $p$ \\
\hline Typical & $9 / 28$ & Aneuploid & & \\
WDNC (atypical) & $17 / 25$ & Aneuploid & 5.44 & $<0.02$ \\
$\begin{array}{l}\text { Differentiated growth } \\
\text { pattern }\end{array}$ & $15 / 21$ & Aneuploid & & \\
$\begin{array}{l}\text { Undifferentiated growth } \\
\text { pattern }\end{array}$ & $11 / 32$ & Aneuploid & 5.6 & $<0.02$ \\
No necrosis & $13 / 35$ & Aneuploid & & \\
Necrosis & $13 / 18$ & Aneuploid & & $<0.05$ \\
Normal nuclei & $5 / 27$ & Aneuploid & & \\
Pleomorphic nuclei & $21 / 26$ & Aneuploid & 18.1 & 0.001 \\
\hline
\end{tabular}

WDNC $=$ well differentiated neuroendocrine carcinoma

Table 2 Bronchial carcinoid neurendocrine protein products $^{46}$

\begin{tabular}{l} 
Peptides \\
Amylase \\
Bombesin \\
Calcitonin \\
Corticotrophin \\
Corticotrophin releasing hormone \\
Gastrin \\
Glucagon \\
Growth hormone releasing factor \\
Human chorionic gonadotrophin \\
Insulin \\
Melanocyte stimulating hormone \\
Motilin \\
Neurotensin \\
Pancreatic polypeptide \\
Secretin \\
Somatostatin \\
Substance K \\
Substance P \\
Vasoactive intestinal polypeptide \\
Vasopressin \\
Vasoactive amines \\
Catecholamines \\
Histamine \\
Kinins \\
Bradykinins \\
Tachykinins (neurokinin A) \\
Endorphins and enkephalins \\
R-Endorphin \\
Leu-enkephalin \\
Met-enkephalin \\
Pan-opioid \\
Other \\
Kallikrein \\
Prostaglandins \\
\hline
\end{tabular}

11 Wynn SR, O'Connell EJ, Frigas E, Paynes WS, Sachs MI Exercise-induced asthma as a presentation of bronchial carcinoid. Ann Allergy 1986;57:139-41.

12 Grahame-Smith DG. The carcinoid syndrome. London: Heinemann, 1972.

13 Ricci C, Patrassi N, Massa R, et al. Carcinoid syndrome in bronchial adenoma. $A m \mathcal{F}$ Surg 1973;126:671-7.

14 Shalet SM, Beardwell CG, MacFarlane IA, Ellison ML Norman CM, Rees LH, et al. Acromegaly due to production of a growth hormone releasing factor by a bronchial carcinoid tumour. Clin Endocrinol 1979;10:61-7.

15 Yamashina $M$. An 18 year history of a corticotrophinsecreting spindle cell carcinoid of the lung. Arch Pathol Lab Med 1985;109:673-5.

16 Shames JM, Dhurandhar NR, Blackard WG. Insulinsecreting bronchial carcinoid tumor with widespread metastases. Am f Med 1968;44:632-7.

17 Huber RM, Schopol J, Losa M, et al. Growth hormone releasing hormone in a bronchial carcinoid. Cancer 1991; 67:2538-42.

18 Allen MB, Shamash J, Kerr KM, Leetch RG. Hypercalcaemia in atypical bronchial carcinoid tumor. Chest 1989;96:1206-8.

19 Okike N, Bernatz P, Woolmer LB. Carcinoid tumors of th lung. Ann Thorac Surg 1976;22:270-5. year experience. Thorax 1984;39:617-23.

21 Warren WH, Faber LP, Gould VE. Neuroendocrine neoplasms of the lung: a clinicopathologic update. $\mathcal{F}$ Thorac Cardiovasc Surg 1989;98:321-32.

22 Hasleton PS, Al-Saffar N. The histological spectrum of bronchial carcinoid tumours. Appl Pathol 1989;7:205-18. 23 Arrigoni MG, Woolner LB, Bernatz PE. Atypical carcinoid tumors of the lung. $f$ Thorac Cardiovasc Surg 1972;64: 413-21.

24 Mills SE, Walker AN, Cooper PH, Kron IL. Atypical carcinoid tumor of the lung: a clinicopathological study of 17 cases. Am $\mathcal{F}$ Surg Pathol 1982;6:643-54.

25 Hammond ME, Sause WT. Large cell neuroendocrine tumors of the lung. Clinical significance and histopathological definition. Cancer 1983;56:1614-29.

26 Ghadially FN, Block HJ. Oncocytic carcinoid of the lung. f Submicroscop Cytol 1985;17:435-42.

27 Grazer R, Cohen SH, Jacobs JB, Lucas P. Melanin-containing peripheral carcinoid of the lung. Am $\mathcal{f}$ Surg Pathol 1982;61:73-8.

28 Mark EJ, Quay SC, Dickersin GR. Papillary carcinoid tumor of the lung. Cancer 1981;48:316-24.

29 Ranchod M, Levine GD. Spindle-cell carcinoid tumors of the lung: a clinicopathologic study of 35 cases. Am f Surg Pathol 1980;4:315-31.

30 Wise WS, Aikawa M, Border D, Hsieh CL. Carcinoid tumor of the lung with varied histology. Am F Surg Pathol 1982, 6:261-7.

31 Al-Kais W, Abdul-Karim FW, Mendelson G, Jacobs G Bronchial carcinoid tumor with amyloid stroma. Arch Pathol Lab Med 1988;112:211-4.

32 Hasleton PS, Gomm S, Blair V, Thatcher N. Pulmonary . Br 7 Cancer 1986;54:963-7.

33 Thomas CP. Ossifying bronchial adenoma. Thorax 1958; 13:286-93.

34 Cooney T, Sweeney EC, Luke D. Pulmonary carcinoid tumours: a comparative regional study. $\mathcal{F}$ Clin Pathol 1979 32:1100-9.

35 Williams ED, Brown CL, Doniach I. Pathological and clinical findings in a series of 67 cases of medullary carcinoma of the thyroid. $\mathcal{f}$ Clin Pathol 1966;19:103-13.
20 Hurt R, Bates M. Carcinoid tumours of the bronchus: a 33 
36 Vanmaele L, Noppen M, Frecourt N, Impens N, Welch B, $S$ chandevijl W. Atypical ossification in bronchial carcinoid. Eur Respir ₹ 1990;3:927-9.

37 Froesch ER, Schmid C, Schwander J, Zapf J. Actions of insulin-like growth factors. Annu Rev Physiol 1985;47: 443-67.

38 Schoenle E, Zapf J, Humbel RE, Froesch ER. Insulin-like growth factor I stimulates growth of hypophysectomised rats. Nature 1982;296:252-3.

39 Adams SO, Nissley SP, Handwerger S, Rechler MM. Developmental patterns of insulin-like growth factor-I and -II synthesis and regulation in rat fibroblasts. Nature 1983; 302:150-3.

40 Al-Saffar N, Moore JV, Hasleton PS. A morphometric analysis of individual cell death in bronchial carcinoids. Cell lysis of individual cell death

41 Moore JV. Death of cells and necrosis of tumours. In: Perspectives on mammalian cell death. Oxford: Oxford University Press, 1987:295-325

42 Moore JV, Hasleton PS, Buckley CH. Tumour chords in 52 bronchial and cervical squamous cell carcinomas: inferences for their cellular kinetics and radiobiology. $\mathrm{Br} \mathcal{F}$ Cancer 1985;51:407-13.

43 Jones DJ, Hasleton PS, Moore M. DNA ploidy in bronchopulmonary carcinoid tumours. Thorax 1988:43:195-9.

44 El-Naggar A, Ballance W, Abdul Karim F, et al. Typical and atypical bronchopulmonary carcinoids: a clinicopathologic and flow cytometric study. Am $\mathcal{F}$ Clin Pathol 1991; 95: 828-34.
45 Bishopric GA Jr, Ordonez NG. Carcinoembryonic antigen in primary carcinoid tumors of the lung. Cancer 1986;58 1316-20.

46 Davila DG, Dunn WF, Tazelaar HD, Pairolero PC. Bronchial carcinoid tumors. Mayo Clin Proc 1993;68:795-803.

47 Al-Saffar N, White A, Moore M, Hasleton PS. Immunoreactivity of various peptides in typical and atypica bronchopulmonary carcinoid tumours. Br $\mathcal{F}$ Cancer 1988 58:762-6.

48 Gould VE, Linnoila RI, Memoli VA, Warren WN Neuroendocrine cells and neuroendocrine neoplasms of the lung. Pathol Annu 1983;18:287-330.

49 Gould VE, Lee I, Wiedenmann B, Moll R, Chejfec G, Franke WW. Synaptophysin: a novel marker for neurons, certain neuroendocrine cells and their neoplasms. Hum Pathol 1986;17:979-83.

50 Suresh U, Quigley A, Hasleton PS. Pre-albumin staining in bronchial carcinoid tumours $f$ Pathol staining in bron

51 Walts AE, Said JW, Shintaku P, Lloyd RV. Chromogranin as a marker of neuroendocrine cells in cytologic material an immunocytochemical study. Am f Clin Pathol 1985; 84:273-7.

52 Bergh J, Esscher T, Steinholtz L, Nilsson K, Pahlman S. Immunocytochemical demonstration of neuron specific enolase (NSE) in human lung cancers. Am 7 Clin Pathol 1985;84:1-7.

53 Bostanci G, Hasleton PS, Vasudev KS. Neurofilaments in typical and atypical carcinoids. In preparation. 